\title{
The influence of the owner-manager of small tourism businesses on the success of internet marketing
}

\author{
R. Elliott* \\ Department of Management, Rhodes University, \\ PO Box 94, Grahamstown 6140, Republic of South Africa \\ R.Elliott@ru.ac.za \\ C. Boshoff \\ Department of Business Management, University of Stellenbosch, \\ Private Bag X1, Matieland 7600, Republic of South Africa \\ cboshoff@sun.ac.za
}

Received May 2007

\begin{abstract}
Small businesses have been identified as a catalyst for creating jobs and generally growing the economy. One industry that is characterised by the proliferation of small businesses is the tourism industry. Key to this industry reaching its full potential is, however, access to markets. The Internet is seen by many as having the potential to help small tourism businesses understand their markets better, extend their market reach and to serve their customers more effectively, irrespective of their geographical location. However, identifying the factors that influence the success of the use of the Internet for marketing purposes is proving elusive.
\end{abstract}

The focus of this study is to identify those owner-manager factors that are present in a small tourism business which will influence the success with which the Internet can be used to market the business. These are distinct from the factors implicit in the technology per se. If these owner-manager factors can be identified and their relative influence on Internet marketing success is determined, it will allow small tourist businesses to access markets more readily.

The results of this study indicate that the level of involvement of owner-managers, the owner-manager having an entrepreneurial orientation, the knowledge of owner-managers, the involvement in decision making of owner-managers and a marketing orientation are important to the successful use of the Internet for the marketing of small tourism businesses in South Africa.

*To whom all correspondence should be addressed.

\section{Introduction}

The importance of small businesses to economic growth in general and job creation in particular is often emphasised. Some, for instance, point to the high labour absorption capacity of small businesses (Pitt, 1996; Zimmerer \& Scarborough, 2002) suggesting that small businesses generate wealth at a faster rate than larger firms would. Also they point out; the growth in numbers of people employed by small businesses is greater than the growth in the contribution of these enterprises to GDP. For example, in 2001, the increase in people employed by small businesses in South Africa was 1.5 times the growth in the contribution of these entities to GDP (Ntsika, 2002). Small business development, particularly for developing economies, thus becomes an attractive focus area in addressing the perennial problems of unemployment, low economic growth and the subsequent negative impact on social development in general (South Africa, 1995).

Small businesses, however, are not merely a miniature version of large organisations, but have a unique set of qualities (Bridge, O’Neill \& Cromie, 1998; Chaston, 2000; Gilmore, Carson \& Grant, 2001). A key differentiating factor between small businesses and large businesses is the direct influence of the owner-manager on the daily functioning and decision making of the small medium and micro enterprises (SMME) (Carson, Gilmore, Cummins, O’Donnell \& Grant, 1998; Gilmore, Carson \& Grant, 2001).

The influence of the owner-manager on the success of small businesses is pervasive throughout all industries and impacts on all aspects of small business management including the area of marketing. It follows that the study of the ownermanager factors influencing the success of the use of the Internet for marketing is particularly relevant in an industry such as tourism which is characterised by the proliferation of small businesses.

\section{The marketing of small tourism businesses}

Tourism in particular has been identified as a sector that can play a significant role in small business development in South Africa (South Africa, 1996; South Africa, 1998), 
given the fact that the majority of tourism ventures are small business ventures. The importance of tourism to the South African economy is illustrated by the latest estimates from the World Travel and Tourism Council (WTTC), which show that the travel and tourism industry was expected to contribute 2.9 percent to GDP in 2003, rising to 3.6 percent by 2013. The broader travel and tourism economy was expected to contribute 7.3 percent to GDP in 2003, growing to 8.8 percent by 2013. In terms of jobs, it was estimated that in 2003 the travel and tourism industry accounted for 491741 jobs or 2.9 percent of total employment and by 2013 this is anticipated to increase to 751100 jobs or 3.7 percent of the total number of people employed. The total number of jobs in the broader travel and tourism economy was estimated at 1118530 jobs, 6.6 percent of total employment, and by 2013 this is expected to escalate to 1 650140 jobs or 8.2 percent of total employment (WTTC, 2003).

Despite these impressive figures it has been pointed out that tourism is an 'under-performing' sector with considerable potential for expansion (WTTC, 2002). A recent (2002) World Travel and Tourism Council (WTTC) report criticised the progress being made in South Africa in tourism as being unsatisfactory and not accomplishing the targets set by the WTTC in 1996. What the report found particularly disappointing was the failure of the tourism sector to create jobs and develop small businesses (WTTC, 2002).

Small businesses, particularly in the tourism sector, view the lack of market access as a major obstacle inhibiting their growth (Rogerson, 2003; Ntsika, 2002). This perception is corroborated by studies in South Africa and internationally that view market access as a critical factor in business growth (South Africa, 1995). Although all businesses face the daunting task of marketing and competing in a global economy (Graham, 1999), small businesses (defined in this study as businesses that have fewer than 100 employees) in South Africa face a wider range of constraints and problems that inhibit their ability to address the problems facing them than do big businesses.

Utilising the Internet has been suggested as one way of overcoming the marketing challenges faced by small businesses as the Internet allows access to hitherto inaccessible markets irrespective of the size of the business (Haynes, Becherer \& Helms, 1998; Vargha \& Pettigrew, 2001). One cannot ignore the fact that the Internet has fundamentally changed the communication as well as some of the business paradigms of the world (Hoffman \& Novak, 1996). It has allowed new models of commercial interaction to develop as businesses and consumers increasingly participate in the electronic marketplace (Clinton \& Gore, 1997), which allows small businesses to access new markets and compete with larger firms on a more equal footing than ever before. In other words, the Internet is a cost-effective medium that small South African tourism businesses can realistically use to market their businesses both locally and internationally. However, the dominant role an ownermanager in small tourism businesses may cause small firms to differ in the nature and extent of the factors driving Internet marketing success.

\section{Problem statement and objectives}

As with all South African small enterprises, small tourism businesses also face the problem of access to markets (Ntsika, 1998; Ntsika, 2002), which limits its growth potential. The Internet, with its ability to reach broad and new markets at a very low marginal cost (Carr, 2000) has the potential to contribute to the growth of this sector by enhancing its market reach, but, despite the potential of the Internet as a business and marketing tool, its actual use has not met expectations (Hoffman \& Novak, 1996; Hoffman, Novak \& Chatterjee, 1995). One reason offered for the Internet's slow adoption by small businesses is entrepreneurs' apparent poor grasp of the drivers of electronic commerce (Remenyi, 2000). Against this backdrop, it is important to identify the owner-manager factors that influence successful Internet marketing in small tourism businesses.

The primary objective of this study was to investigate and empirically test the possible influences and relationships between the various independent variables that can influence the dependent variable, namely the Perceived success of Internet marketing within the tourism industry. Specifically, the focus of this study is to identify the owner-manager factors specific to the small tourism businesses (rather than the technology per se or Internet-specific factors) driving the success of the use of the Internet for marketing in small businesses operating in the tourism sector in South Africa.

\section{The factors influencing internet marketing success}

Much of the literature on Internet marketing is either anecdotal, conceptual or based on case studies. The limited published quantitative research has predominately taken the form of surveys about the use of the Internet by consumers. This study is different in the sense that an attempt is made to identify and empirically verify the determinants of successful Internet marketing for South African small tourism businesses.

The factors (independent variables) considered in this study are those that are associated with the 'owner-manager issues' of the use of the Internet as a business/marketing tool, rather than issues relating to the implementation of the Internet. The owner-manager -related factors identified and empirically evaluated in this study are (a) the market orientation of the owner-manager; (b) the entrepreneurial orientation of the owner-manager; (c) the knowledge of the owner-manager about the business implications of the Internet; and (d) the owner-manager's involvement in the day-to-day management of the use of Internet for marketing.

\section{Market orientation}

Market orientation is a term used to describe the implementation of the marketing concept. This concept (market orientation) is distinct from marketing orientation, which describes a functional approach to meeting the consumers' needs, whereas the term market orientation describes an organisation-wide approach (Lafferty \& Hult, 2001). However, these terms are often confused and in some 
cases are used interchangeably (Gray, Matear, Boshoff \& Matheson, 1998).

The issue of what comprises market orientation is complex and Lafferty and Hult (2001) distinguish between five different approaches to understanding the market orientation concept. In their study, Lafferty and Hult (2001) synthesise the areas of overlap contained in these different approaches and conclude that there are four dimensions of marketing orientation that are pervasive in these different approaches: the primacy of customers as a focus; the value of shared market intelligence; inter-functional coordination of marketing activities and implementing the apposite action, where necessary. Although there is no consensus on the definition of market orientation, the models of Kohli and Jaworski (1990) and Narver and Slater (1990) are generally accepted as incorporating most of the essential elements of the marketing orientation construct (Gray et al., 1998).

Narver and Slater (1990) argue that there are three behavioural components making up the market orientation construct, which they label as customer market orientation, competitor market orientation and inter-functional orientation, as well as two decision criteria, namely long term focus and profit objective. Customer orientation is understood as the function of understanding the needs of customers in order to provide them with sustainable value. Competitor orientation is ensuring that the business appreciates its competitor's capabilities and strategies. Lastly, inter-functional coordination refers to the coordination between the businesses various components to ensure customer value (Narver \& Slater, 1990).

By contrast, Kohli and Jaworski (1990) argue that that market orientation is best viewed as a continuum rather than as a dichotomous construct. They identified the generation of market intelligence, the dissemination of this information and the response of the business as key issues in this construct. However, research by Venkatesan and Soutar (2000) revealed that the construct developed by Narver and Slater (1990), with the exception of the factor measuring inter-functional coordination, was the most appropriate to measure market orientation in small businesses.

Much of the research in this area has been directed towards establishing a link between market orientation and improved financial returns. Research (Greenley, 1995; Narver \& Slater, 1990; Pitt, Caruana \& Berthon, 1996) has found that market orientation is positively correlated with improved financial results; although it is conceded that this relationship is not always entirely clear (Pelham, 2000). The link between market orientation and improved financial returns is based on the rationale of maintaining a sustainable competitive advantage (Pelham \& Wilson, 1996) and this principle applies equally in small businesses (Megginson, Byrd \& Megginson, 2000).

Although there is some support for the link between market orientation and improved returns in studies done in the United States of America (Kohli \& Jaworski, 1990; Narver \& Slater, 1990), Greenley (1995), in a study done in the United Kingdom, found that the link was not as direct as suggested by these two American studies (Kohli \&
Jaworski, 1990; Narver \& Slater, 1990) and that the impact of market orientation may be diminished by other variables. In particular, Greenley (1995) found that market orientation may not be effective in facilitating improved financial returns in extremely turbulent markets, under conditions of low customer power or under conditions characterised by rapid technological change.

Pelham and Wilson (1996) argue that, because small businesses often lack systematic strategic planning and thinking, market orientation could provide smaller firms with the necessary focus to overcome this impediment in that it allows them to focus on their source of competitive advantage. Many successful small businesses are not market-orientated and although it could be argued that a market orientation is not essential to ensure success (Carson, Cromie, McGowan \& Hill, 1995), globalisation and the advent of the Internet have given this construct new momentum (Pelham, 2000) as these developments have also brought more intense competition.

A business's market orientation could be expected to enhance the integration of the Internet into the small tourism business. The basis of this argument is that a market orientation enhances the learning in the business that is crucial during the implementation of a technological innovation such as the Internet (Hoffman \& Novak, 1997; Morgan, Katsikeas \& Appuh-Adu, 1998). A market orientation allows small tourism businesses to use the Internet to maintain a competitive advantage, as it facilitates customer, market and technology intelligence (Hoffman \& Novak, 1997; Jones, Hecker \& Holland, 2003). This conclusion is supported by research that suggests that the degree to which a business successfully introduces innovations, such as new products, depends on the extent and nature of its market orientation (Atuahene-Gima \& Ko, 2001; Hurley \& Hult, 1998). Thus, we conclude, that smaller tourism businesses that strive to engender a culture of market orientation, through the dominant influence of the owner-manager, will have a better chance of successfully using the Internet for marketing purposes.

\section{Entrepreneurial orientation}

The definitions of what is meant by entrepreneur and entrepreneurship are diverse and consensus is a long way off (Carland, Hoy, Boulton \& Carland, 1984; Poon \& Swatman, 1997). This state of affairs exists in spite of the fact that the first entrepreneurial theories originated in the $18^{\text {th }}$ century (Guzman-Cuevas, 1994). It is argued that entrepreneurship involves viewing the business environment from a fresh and unique perspective (Morris, Kuratko \& Schindehutte, 2001).

There are a number of similarities between entrepreneurship and marketing, including the fact that both have a customer focus (Hisrich, 1992), are strongly influenced by changes in the environment (Hisrich, 1992; Carson et al., 1995) and that both involve innovation and change (McGowan \& Durkin, 2002). Although the concepts of small business and entrepreneurship may overlap, they are distinct entities (Carland et al., 1984) and one must acknowledge that entrepreneurial conduct may extend to large firms (Collinson \& Shaw, 2001). Implicit in this argument is that 
many small businesses may not be entrepreneurial (Chaston, 2000; Megginson et al., 2000).

It is trite to say that the advent of the Internet has inexorably altered the marketing environment of small businesses by doing away with spatial and time barriers. Conventions and practices that have been accepted for many years are no longer tolerable (Haynes et al., 1998; Vargha \& Pettigrew, 2001). This unpredictability is typical of hostile environments that require an entrepreneurial orientation to negotiate successfully (Covin \& Slevin, 1989).

It is often argued that innovation is one characteristic that distinguishes entrepreneurial businesses from those that are not (Carland et al., 1984). An entrepreneurial orientation also includes the propensity to take risks (Covin \& Slevin, 1989; Miller, 1983; Miller \& Friesen, 1983), although Schumpeter (1934) argued that taking risks is inherent in the ownership of a business. This view is supported by the research of Brockhaus (1980), which suggested that a risktaking propensity could not be used as a characteristic to distinguish between entrepreneurs and non-entrepreneurs. Covin and Slevin (1989) argue that entrepreneurial conduct entails taking more risks than non-entrepreneurial behaviour. In other words, the concept of risk can be viewed as existing in a continuum with non-entrepreneurial businesses embracing moderate or low risk and entrepreneurial firms taking on higher degrees of risk.

In addition to innovation and the taking of risks, entrepreneurial orientation includes the degree to which owner-managers embrace change (Covin \& Slevin, 1989; Miller, 1983; Miller \& Friesen, 1983). This view is supported by Hills and LaForge (1992), who, in a review of the entrepreneurship literature, conclude that entrepreneurship requires the creation of new entities, innovation, uniqueness and growth.

Miller (1983), surveying large businesses in Canada, found a significant correlation between their success in hostile environments and entrepreneurial orientation (operationalised as innovation, proactiveness and risk taking). However, the results of a study by Miller and Friesen (1983), also in respect of large businesses, were inconclusive. A study by Khandwalla (1977), in respect of small businesses, found that an entrepreneurial management style was more apposite in a hostile environment, although he did operationalise entrepreneurial orientation differently from Miller (1983) and Miller and Friesen (1983). However, Covin and Slevin (1989) found that, in hostile environments, performance by small businesses with a high entrepreneurial orientation was superior to that of small firms with low levels of entrepreneurial orientation.

These findings are consistent with the research of Poon and Swatman (1997) and Bengtsson, Boter \& Vanyushyn (2003), who argue that the level of entrepreneurship in a business may be one of the requisites in successfully utilising the Internet. This view is consistent with the work of Schumpeter (1942) who points out that entrepreneurs have the important function of not only initiating, but also transforming an innovation from an idea into reality. Entrepreneurs are able to play this catalytic role because they typically have both the capacity to identify opportunities, as well as the capacity to coordinate the resources necessary to utilise the opportunity (AtuaheneGima \& Ko, 2001).

Thus, we conclude, that owner-managers of small tourism businesses that posses a true entrepreneurial orientation will have a better chance of using the Internet successfully for marketing purposes.

\section{Owner-manager knowledge}

Some level of technical knowledge by the owner-manager has been found to be an important factor in the successful adoption and implementation of information technology systems (Cragg \& King, 1993; Thong \& Yap, 1995), as it has for the Internet (McGowan \& Durkin, 2002; Mehrtens, Cragg \& Mills, 2001).

In order to integrate the Internet as a core tool for marketing, Durkin and McGowan (2001) posit that 'technical ability' is a competency that needs to be acquired by the ownermanager. They argue that this technical capability does not necessarily mean that the owner-manager is able to implement all the technical elements of this technology, but rather that the owner-manger at least appreciates the fundamental issues pertaining to its management and utilisation. Technical ability, however, did not necessarily presuppose a broader appreciation of the strategic benefits that the Internet could facilitate.

Others argue that innovations such as the Internet require a knowledge that is greater than a general appreciation of the technology (Jones et al., 2003). They seem to believe that the successful implementation of complex innovations (such as the Internet), in addition to a basic understanding of the principles, requires specialised knowledge of how to operate the technology (Rogers, 1995). However, research done by Poon and Swatman (1997) found that the majority of the owners of the small businesses they surveyed had not received any formal training in information technology.

The other school of thought believes that the ownermanager of a small tourism business does not necessarily have to have the technical competence to implement the Internet personally, as much of the required knowledge could be sourced from his personal contact network (McGowan, Durkin, Allen, Dougan \& Nixon, 2001). Reality often confirms this contention. A study by Yeung, Shim and Lai (2003), who conducted research into the adoption of ecommerce by small and medium enterprises in Hong Kong, found that 69 percent of businesses with Web sites relied on outside service providers to design and maintain their Web sites. Nevertheless, a reasonable knowledge and understanding of the Internet by the owner-manager of a small business is necessary for the successful implementation of the Internet for marketing (Stansfield \& Grant, 2003), as often only the owner-manager appreciates the critical issues in a small business and is in a position to make informed decisions (O’Toole, 2003; Delone, 1988).

It thus appears as if the knowledge that owner-managers of small tourism businesses have of the Internet will be related to the successful use of the Internet for marketing purposes. 


\section{Owner-manager involvement}

Durkin and McGowan (2001) developed a theoretical model that attempted to describe the role and importance of the Internet on the marketing activities of entrepreneurial businesses. The model attempted to explain the competencies that such a business would need to be able to move from conceptualising the possible utilisation of the Internet as a marketing tool to its successful implementation. They argue that the first competency that is required is that the entrepreneur should have a 'vision' of what the Internet can achieve. The second competency was termed 'value', which implies that the owner-manager takes his vision further and actually acquires the technology and technical competencies to utilise this medium. The third competency is that of 'technical ability' and the last competency proposed is that of 'control'. This competency-based model implies that the owner-manager manages the Internet within the context of the overall business and marketing activities on a continuous basis (Durkin \& McGowan, 2001). Clearly, however, these steps would require a substantial commitment in terms of time by the owner-manager, and if this were not forthcoming, it would compromise the effective implementation of an information system such as the Internet (Cragg \& King, 1993).

McGowan et al (2001), attempted to test the model developed by Durkin and McGowan (2001), by conducting 25 in-depth interviews with small business entrepreneurs who used the Internet. The study was conducted across a number of different sectors within the context of using the Internet to manage buyer-seller relationships. The results confirmed the importance of the involvement of the ownermanager in the everyday management of Internet marketing (as did the research of McGowan and Durkin, 2002). These findings are supported by the earlier research by Delone (1988), in respect of information technology, which found that where computers are onsite, availability is correlated with their successful use. It was argued that the reason for this was that where the computers were on the premises, as opposed to in a remote location, they triggered management involvement in their use. In small businesses, it is not uncommon that only the owner-manager has access to information and resources to make and implement appropriate decisions (O’Toole, 2003) and this finding is particularly germane to small tourism businesses because of the inseparability of production and consumption (Palmer, 2005).

Thus, we suggest that owner-manager involvement in the use of the Internet as a marketing tool will enhance the probability of successful Internet marketing in small tourism organisations.

\section{Methodology}

\section{The measuring instrument}

In order to ensure validity and reliability, measuring instruments from previous studies were, where possible, used to measure both the independent variables and the dependent variable. There are, however, few reliable scales to measure most of the aspects related to e-business ( $\mathrm{Wu}$,
Mahajan \& Balasubramanian, 2003). Where instruments were inadequate or unavailable, additional questions were formulated, based on the literature, to ensure that each construct was measured by at least five items. All the items in the questionnaire were linked to a 7-point Likert-type scale where 1 was labelled strongly agree and 7 was labelled strongly disagree.

Ten items (derived from the literature and preliminary qualitative research) were formulated to measure the dependent variable of the Perceived success of Internet marketing.

\section{The sample}

Despite the importance of tourism in creating employment and generally growing the economy in South Africa, there is no comprehensive database of tourism operators in South Africa (Myles, 2003; Seymour, 2002). Although the various tourism authorities have databases of tourism businesses, these are not comprehensive as registration with these organisations is not mandatory.

The databases of tourism businesses registered with the Western Cape Tourism authority, KwaZulu-Natal Tourism authority and the Eastern Cape Tourism authority were obtained. In the case of the Eastern Cape database, this was supplemented by the databases of the tourism authorities of Buffalo City, Nelson Mandela Metropolis and the Wild Coast, as there was no integration of these various databases. These databases were used to elicit the contact details of those small tourism businesses with Web sites, which were used as the qualifying criterion to define those tourism businesses that use the Internet to market their businesses. The population of this study was the databases of the various tourism authorities described above and implies the use of a convenience sampling technique.

Altogether 2011 potential respondents were surveyed using a Web based questionnaire that allowed respondents to complete the questionnaire online. The 316 usable questionnaires received comfortably exceed the minimum guideline for the use of multivariate statistical procedures to analyse the data (Hair, Anderson, Tatham \& Black, 1998).

\section{Statistical procedures}

\section{Validity assessment}

The initial step in the data analysis was to assess the discriminant validity of the instrument used to measure the variables in the theoretical model. This was done using the multivariate technique of exploratory factor analysis with the purpose of establishing which of the questionnaire items measure each construct (and only that construct) in the theoretical model. The exploratory factor analysis was done using the computer programme SPSS (version 13.0). Based on the recommendations of Gorsuch (1997) and Fabrigar, Wegener, MacCullum \& Strahan (1999) a Direct Quartimin Oblique rotation with a Principal-Axis extraction was used to factor analyse the data. 
The eigen values in combination with the scree test were initially used to decide how many factors ought to be extracted. These two considerations suggested that the extraction of five variables would be appropriate.

These factors were identified by an iterative process, deleting items that either did not load higher than 0.45 on any factor or alternatively loaded more than 0.45 or higher on two or more factors (cross-loading). The most interpretable factor structure to emerge from this iterative process is the one depicted in Table 1.

\section{Reliability of the measuring instrument}

Reliability refers to the extent to which measures or data are free from error and therefore yield consistent, reproducible results. In other words, the reliability of an instrument thus depends on how much of the variation in scores is attributable to random error (Churchill, 1979). Reliability is thus the consistency or stability of empirical indicators from measurement to measurement (Parasuraman, 1991). If the association between the different items is high, they are consistent in giving the same results and therefore reliable (Parasuraman, 1991).

One way of measuring reliability is using Cronbach's alpha coefficient, which is based on the average correlation of items within an instrument or scale and is regarded as an indication of internal consistency.

\section{Results}

\section{Discriminant validity results}

The factor matrix of the exploratory factor analysis is shown in Table 1. It reveals that the 35 items loaded on six distinct factors, explaining a total of 49.4 percent of the variance in the data. The six factors were named Owner-manager involvement, Entrepreneurial orientation, Perceived success of Internet marketing, Owner-manager knowledge, Ownermanager decision-making and Marketing orientation. These factors are discussed in detail below and the items that measure each factor are described in Appendix 1.

Six items (OI1, OI2, OI3, OI4, OI5 and OI6) were originally used to measure the construct Owner-manager involvement. The exploratory factor analysis results revealed however, that this construct consists of two underlying dimensions. Two these items (OI2 and OI3) loaded on one factor (Factor 5) with a further two items (OI5 and OI6) loading on Factor 1. Factor 5 was named Owner-manager decision-making and is operationalised as the extent to which the ownermanagers are involved and participate in decision making about the Internet marketing of their businesses. In contrast, Factor 1 was named Owner-manager involvement and is operationalised as the extent to which the owner-manager is involved in the everyday managing of the small tourism business' Internet marketing initiative.

Entrepreneurial orientation was originally operationalised as comprising three different dimensions. These were innovation (five items), proactive orientation (two items) and risk-taking propensity (three items). However, an exploratory factor analysis was done on this construct on its own and the eigenvalues suggested that the construct was uni-dimensional. High inter-correlations provided further support for this conclusion.

Nine of the original eleven items included to measure entrepreneurial orientation all loaded on Factor 2, of which five (EO1, EO2, EO3, EO4 and EO5) were initially formulated to measure innovation, one (EO6), proactive orientation and the remaining two items (EO9 and EO10), risk-taking propensity. In addition, one item (COM1), originally formulated to measure the Competitor orientation dimension of Marketing orientation also loaded on this factor. This is understandable as it refers to the monitoring of competition which is implicit in the proactive orientation dimension of entrepreneurial orientation. In other words, Entrepreneurial orientation is operationalised as the extent to which businesses are innovative in their marketing practices, have recently significantly changed the nature of or added features to their service, constantly refine and develop existing services, monitor competition, are often the first business to introduce new products and constantly explore the development of new business ideas, take bold and aggressive decisions and have the tendency to embark on risky projects.

Seven items (COM1-7) were originally formulated to measure the Competitor orientation dimension of Marketing orientation. Three of these items (COM3, COM4 and COM6) loaded on factor 6. In addition three (CUS4, CUS6 and CUS7) of the original five items included in the measuring instrument to measure the Customer orientation dimension of Marketing orientation loaded on factor 6 . Accordingly, Marketing orientation is operationalised as the extent to which the business understands its competitors, as well as their (the competitors') approach to marketing, monitors customer preferences and is concerned with customer satisfaction.

Factor 4 was labelled Owner-manager knowledge and comprised four items (TK2, TK3 TK4 and TK5) of the six items expected to measure the construct. One item expected to measure owner involvement (OI4) loaded on this factor as well, which was regarded as an additional measurement of the Owner-manger knowledge variable as it refers to the owner-manager monitoring the progress of Internet marketing which, we argue, would be implicit in appreciating the business issues surrounding the firm's use of the Internet for marketing.

The construct of Owner-manager knowledge is defined as the extent to which the owner-manager of a small tourism business appreciates, monitors and understands the business implications of the Internet, which allows him to make informed decisions about the use of the Internet for marketing purposes.

The ten items (SUC1-10) which were originally formulated to measure the dependent variable in this study, the Perceived success of Internet marketing all loaded on Factor 3. In other words the Perceived success of Internet marketing is operationalised as the extent of the satisfaction of owner-manager regarding the impact of the Internet on improving the efficiency of marketing, sales performance, customer satisfaction, relationship development, market 
research, image and/or brand, promotion and customer service.

The results of the exploratory factor analysis revealed that the independent variables in this study have demonstrated sufficient discriminant validity. Table 1 shows six distinct underlying factors that are not only interpretable but each item measures only one underlying construct.

\section{Reliability results}

The next step was to assess the internal reliability of the five factors that emerged from the exploratory factor analysis. All six factors identified in Table 2 returned a Cronbach alpha coefficient score in excess of 0.70 and are accordingly considered reliable (Cooper \& Emory, 1995; Sekaran, 2000).

Table 1: Exploratory factor analysis results

\begin{tabular}{|c|c|c|c|c|c|c|}
\hline Item & $\begin{array}{c}\text { Factor One } \\
\text { Owner- } \\
\text { manager } \\
\text { involvement }\end{array}$ & $\begin{array}{c}\text { Factor Two } \\
\text { Entrepreneurial } \\
\text { Orientation }\end{array}$ & $\begin{array}{c}\text { Factor Three } \\
\text { Perceived } \\
\text { success of } \\
\text { Internet } \\
\text { marketing } \\
\end{array}$ & $\begin{array}{c}\text { Factor Four } \\
\text { Owner- } \\
\text { manager } \\
\text { knowledge }\end{array}$ & $\begin{array}{c}\text { Factor Five } \\
\text { Owner- } \\
\text { manager } \\
\text { decision } \\
\text { making }\end{array}$ & $\begin{array}{l}\text { Factor Six } \\
\text { Marketing } \\
\text { orientation }\end{array}$ \\
\hline 015 & 0,887 & & & & & \\
\hline 016 & 0,490 & & & & & \\
\hline E06 & & 0,694 & & & & \\
\hline EO1 & & 0,678 & & & & \\
\hline EO5 & & 0,645 & & & & \\
\hline EO2 & & 0,623 & & & & \\
\hline EO3 & & 0,605 & & & & \\
\hline EO8 & & 0,571 & & & & \\
\hline EO4 & & 0,563 & & & & \\
\hline EO10 & & 0,552 & & & & \\
\hline EO9 & & 0,497 & & & & \\
\hline COM2 & & 0,447 & & & & \\
\hline SUC2 & & & 0,779 & & & \\
\hline SUC8 & & & 0,775 & & & \\
\hline SUC9 & & & 0,750 & & & \\
\hline SUC10 & & & 0,666 & & & \\
\hline SUC3 & & & 0,655 & & & \\
\hline SUC5 & & & 0,633 & & & \\
\hline SUC7 & & & 0,616 & & & \\
\hline SUC4 & & & 0,488 & & & \\
\hline SUC6 & & & 0,484 & & & \\
\hline SUC1 & & & 0,454 & & & \\
\hline TK3 & & & & 0,831 & & \\
\hline TK4 & & & & 0,795 & & \\
\hline TK5 & & & & 0,700 & & \\
\hline TK2 & & & & 0,646 & & \\
\hline OI4 & & & & 0,483 & & \\
\hline OI2 & & & & & 0,711 & \\
\hline OI3 & & & & & 0,669 & \\
\hline CUS4 & & & & & & 0,745 \\
\hline COM6 & & & & & & 0,696 \\
\hline COM3 & & & & & & 0,561 \\
\hline CUS6 & & & & & & 0,512 \\
\hline COM4 & & & & & & 0,493 \\
\hline CUS7 & & & & & & 0,467 \\
\hline
\end{tabular}

Notes: 1. Loadings of greater than 0.45 were considered significant.

2. The items included in the factor analysis are provided in Appendix 1. 
Table 2: Cronbach alpha coefficients

\begin{tabular}{l|c}
\hline \multicolumn{1}{c|}{ Factor } & Cronbach Alpha \\
\hline $\begin{array}{l}\text { Factor 1: Owner-manager } \\
\text { involvement }\end{array}$ & 0,868 \\
\hline Factor 2: Entrepreneurial Orientation & 0,874 \\
\hline $\begin{array}{l}\text { Factor 3: Perceived success of } \\
\text { Internet marketing }\end{array}$ & 0,911 \\
\hline Factor 4: Owner-manager knowledge & 0,915 \\
\hline $\begin{array}{l}\text { Factor 5: Owner-manager decision } \\
\text { making }\end{array}$ & 0,774 \\
\hline Factor 6: Marketing orientation & 0,812 \\
\hline
\end{tabular}

\section{The hypotheses}

Based on the literature review the following hypotheses were empirically tested:

$\mathrm{H}^{1}$ : There is a positive relationship between the ownermanager's involvement in the management of Internet marketing and the perceived success of Internet marketing.

$\mathrm{H}^{2}$ : There is a positive relationship between the existence of entrepreneurial orientation in small tourism businesses and the perceived success of Internet marketing

$\mathrm{H}^{3}$ : There is a positive relationship between the extent of the owner-manager's knowledge of the business implications of marketing over the Internet and the perceived success of Internet marketing.

$\mathrm{H}^{4}$ : There is a positive relationship between the participation of the owner-manager in decision making about Internet marketing and the perceived success of Internet marketing.

$\mathrm{H}^{5}$ : There is a positive relationship between the existence of a marketing orientation in small tourism businesses and the perceived success of Internet marketing

\section{Multiple regression analysis results}

A multiple regression analysis was conducted to address the hypotheses. The multiple analysis results with the five independent variables shown in Table 1 (Owner-manager involvement, Entrepreneurial orientation, Owner-manager knowledge, Owner-manager decision-making and Marketing orientation) and Perceived success of Internet marketing as dependent variable are shown in Table 3.

It is apparent from Table 3 that all of the independent variables namely Owner-manager involvement, Entrepreneurial orientation, Owner-manager knowledge, Owner-manager decision-making and Marketing orientation exert a positive influence on the dependent variable Perceived success of Internet marketing. In other words, Hypotheses $\mathrm{H}^{1}, \mathrm{H}^{2}, \mathrm{H}^{3}, \mathrm{H}^{4}$ and $\mathrm{H}^{5}$ are accepted.
Table 3: Multiple regression results: determinants of successful internet marketing

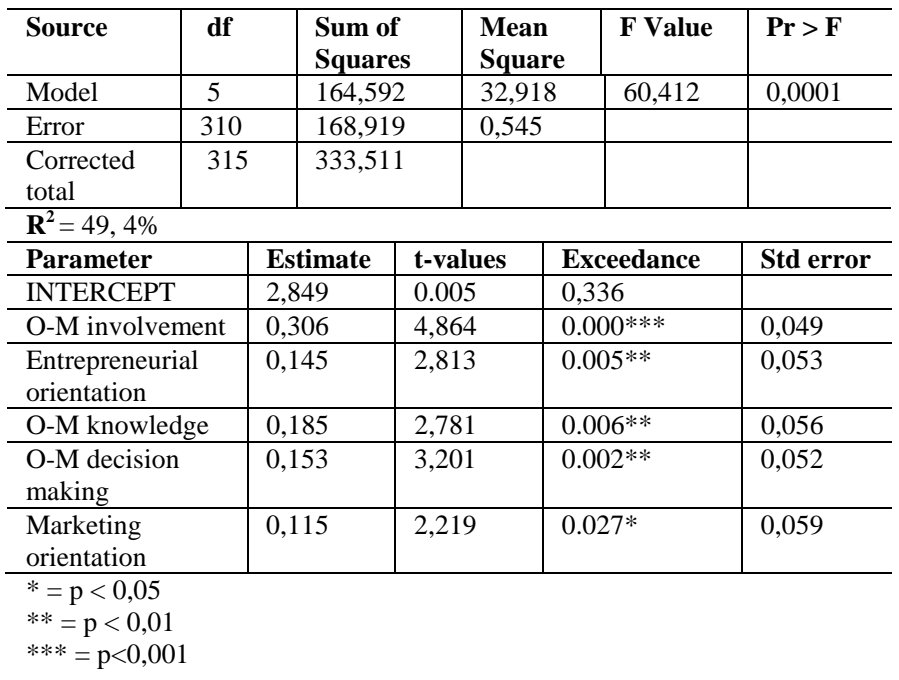

Table 3 also shows that the independent variables in the multiple regression analysis explain 49.4 percent of the variance in the dependent variable Perceived success of Internet marketing.

\section{Owner-manager involvement}

It is apparent from Table 3 that there is a significant positive relationship (Owner-manager involvement and the Perceived success of Internet marketing at the 0.1 percent level. In other words, Hypothesis $\mathrm{H}^{1}$ is accepted as there is support for the assertion that Owner-manager involvement has a positive influence on the Perceived success of Internet marketing. This result indicates that the success of Internet marketing is influenced by the involvement of the ownermanager in the day-to-day management of the Internet for marketing. Furthermore, this result implies that it is not satisfactory for the owner-manager to delegate the day-today management of the small tourism businesses' Internet marketing to someone else, either inside or outside the business as this may compromise the success of Internet marketing. This result is consistent with previous research that emphasised the importance of the involvement of the owner-manager in the use of the Internet for marketing (Cragg \& King, 1993; Delone, 1988; Durkin \& McGowan, 2001; McGowan \& Durkin, 2002; McGowan et al., 2001).

\section{Entrepreneurial orientation}

The empirical results shown in Table 3 support the hypothesis $\left(\mathrm{H}^{2}\right)$ that there is a significant relationship between Entrepreneurial orientation and the Perceived success of Internet marketing. This finding is consistent with previous research, which has demonstrated that the existence of an entrepreneurial orientation will positively impact on the success of Internet marketing (Bengtsson et al., 2003; Jones et al., 2003; Poon \& Swatman, 1997), although in this study, entrepreneurial orientation is comprised predominately of the items making up the innovation dimension (five items), one item from the proactive orientation with a further two items originally formulated to measure the risk-taking propensity dimension. 
This finding also supports the argument that businesses with an entrepreneurial orientation are better able to operate in a volatile and unpredictable environment (Covin \& Slevin, 1989; Miller, 1983; Miller \& Friesen, 1983), which is characteristic of the use of the Internet for marketing. Furthermore, an entrepreneurial orientation will allow a firm to visualise the benefits of Internet marketing, which will in turn facilitate the appropriate learning behaviours.

\section{Owner-manager knowledge}

Empirical support was found for the hypothesised relationship between Owner-manager knowledge and Perceived success of Internet marketing (hypothesis $\mathrm{H}^{3}$ ). Whether the owner-manager appreciates, monitors and understands the business implications of the Internet or not will therefore have a direct impact on the success of the Internet marketing of a small tourism business. Hypothesis $\mathrm{H}^{3}$ is accordingly accepted.

This finding is consistent with research in respect of information systems (for example Cragg and King, 1993; Thong and Yap, 1995), which found that while ownermanagers did not need to be experts in information technology, a reasonable level of technical knowledge is important for its successful adoption and implementation. However, these findings (Cragg \& King, 1993; Thong \& Yap, 1995) can be distinguished from the research in respect of the use of Internet for marketing, which emphasised the importance of the owner-manager appreciating and understanding the broader business implications of the Internet for marketing, in order to coordinate this medium to achieve marketing goals, as opposed to an understanding of the technology per se. Nevertheless, the empirical findings in this study support the research in respect of the importance of the owner-manager's grasp of the business implications of the use of the Internet for marketing (Mehrtens et al., 2001; McGowan \& Durkin, 2002).

\section{Owner-manager decision making}

It is apparent from Table 3 that Owner-manager decisionmaking has a significant influence at the 1 percent level on the Perceived success of Internet marketing and hypothesis $\mathrm{H}^{4}$ is accordingly accepted. This result implies that the extent to which the owner-managers are involved and participate in decision making about the Internet marketing of their businesses will have an impact the success of Internet marketing.

The empirical findings in this study support previous research that emphasised the importance of owner-manager involvement in decision making in regard to Internet marketing. The rationale behind these earlier findings is that in small businesses, only the owner-manager usually has access to the information and resources necessary to make and implement appropriate decisions (McGowan \& Durkin, 2002; McGowan et al., 2001; O’Toole, 2003).

\section{Marketing orientation}

The empirical results reflected in Table 3 indicate that that there is a significant relationship between Marketing orientation and the Perceived success of Internet marketing (hypothesis $\mathrm{H}^{5}$ ). In other words, whether or not a business understands its competitors, as well as their (the competitors') approach to marketing, monitors customer preferences and is concerned with customer satisfaction will significantly (at the 5 percent level ) affect the success of their use of the Internet for marketing

The importance of a market orientation (which has its foundation in the approach of the owner-manager) is that it facilitates learning within a business, which is an important attribute if a business is to successfully use the Internet for marketing (Hoffman \& Novak, 1997; Morgan et al., 1998). In particular, the customer orientation dimension facilitates the collection of information about customers (Hoffman \& Novak, 1997; Jones et al., 2003), as well as organisational learning, which is crucial during the planning and implementation of Internet marketing (Hoffman \& Novak, 1997; Morgan et al., 1998). This finding is consistent with research in respect of innovations (Atuahene-Gima \& Ko, 2001; Hurley \& Hult, 1998), which concluded that a firm's market orientation will impact on the extent to which it successfully introduces innovations.

\section{Managerial implications}

The Internet has inexorably altered the marketing environment of small tourism businesses. There is little certainty on how best to exploit this nascent medium for the marketing of small tourism businesses. The literature revealed that, in an uncertain environment, such as that which characterises the field of Internet marketing, an entrepreneurial orientation will contribute positively to the success of an initiative in this sphere. The literature overwhelmingly concurs with the findings of this study on the significance of an entrepreneurial orientation in the implementation of the Internet for marketing.

The importance of an owner-manager possessing an entrepreneurial orientation is that it allows small tourism businesses to visualise the benefits that Internet marketing yields. This vision in turn drives the plan on how to achieve these goals and the allocation of appropriate resources. In large businesses, planning may be driven by objective and collective decision-making, which is not atypical for small businesses, given the significant influence of the ownermanager.

However, while an entrepreneurial orientation will provide a focus for the use of the Internet for marketing and the constructs of Owner-manager involvement, Owner-manager knowledge and Owner-manager decision making, the means of implementing these objectives, a marketing orientation will assist in obtaining the information on which the ownermanager can base decisions. This is because a market orientation will facilitate the acquisition of information on competitors, the appreciation of customer preferences and understanding the drivers of customer satisfaction.

In conclusion, the results confirm, as with most aspects of successfully managing a small business, the critical role played by the owner-manager in the successful implementation of Internet marketing. It follows that a 
'hands-off' approach by an owner-manger will militate against the successful use of the Internet for marketing in small tourism businesses. However, although these results are significant, a caveat is that these are not the only factors which will the successful implementation of the Internet for marketing in small tourism businesses.

\section{Limitations of the study}

One limitation of the study is that perceptions were measured. In other words the study reports what the managers of small tourism establishments believe is the case rather than 'hard facts'. For instance the success of their Internet marketing endeavours were not measured in terms if 'hits' or number of bookings over the Internet. However, there are no absolute measures for evaluating marketing performance and it essentially comprises measuring results against expectations (Bonoma, 1989; Connor \& Tynan, 1999). This difficulty is compounded in respect of Internet marketing as it is difficult to isolate the impact of this medium on various measures of marketing success (Chaffey, Mayer, Johnston \& Ellis-Chadwick, 2000).

Also, only Owner-manager related variables' impact on marketing success was investigated. Other more general organisational-type variables may also impact on Internet marketing success. More objective assessments of marketing success and the inclusion of a wider variety of variables that can drive Internet marketing success leave scope for future research.

\section{References}

Atuahene-Gima, K. \& Ko. A. 2001. 'An empirical investigation of the effect of market orientation and entrepreneurship orientation alignment on product innovation', Organization Science, 12(1): 54-53.

Bengtsson, M., Boter, H. \& Vanyushyn, V. 2003. 'The challenge of building marketing channels via the Internet'. Paper presented at the International Council for Small Business (ICSB) 2003 conference, 15-18th June 2003. Belfast, Northern Ireland.

Bonoma, T. V. 1989. 'Marketing performance - What do you expect?’, Harvard Business Review, 67(5): 44-47.

Bridge, S., O’Neill, K. \& Cromie, S. 1998. Understanding enterprise, entrepreneurship and small business. London: MacMillan Press Ltd.

Brockhaus, R. H. 1980. 'Risk taking propensity of entrepreneurs', Academy of Management Journal, 23(3): 509-520.

Carland, J. W., Hoy, F., Boulton, W. R. \& Carland, J. C. 1984. 'Differentiating entrepreneurs from small business owners: A conceptualization', Academy of Management Review, 9(2): 354-349.

Carr, N. G. 2000. 'Hypermediation: Commerce as clickstream', Harvard Business Review, 78(1): 46-47.
Carson, D. J., Cromie, S., McGowan, P. \& Hill, J. 1995. Marketing and entrepreneurship in SMEs: An innovative approach. London: Prentice Hall.

Carson, D. J., Gilmore, A., Cummins, D., O’Donnell, A. \& Grant, K. 1998. 'Price settings in SMEs: Some empirical findings', Journal of Product and Brand Management, 7(1): 74-86.

Chaffey, D., Mayer, R., Johnston, K. \& Ellis-Chadwick, F. 2000. Internet marketing, strategy, implementation and practice. Harlow, UK: Prentice Hall.

Chaston, I. 2000. Entrepreneurial marketing: Competing by challenging convention. London: Macmillan.

Churchill, G. A. 1979. 'A paradigm for developing better measures for marketing constructs', Journal of Marketing Research, 16(1): 64-73.

Clinton, W. J. \& Gore, A. 1997. 'A framework for global electronic commerce'. [online] URL: http: //www.iitf.nist.gov/eleccomm/ecomm htm\#no.1 Accessed 21 December 2001.

Collinson, E. \& Shaw, E. 2001. 'Entrepreneurial marketing A historical perspective on development and practice', Management Decision, 39(1): 761-766.

Connor, P. \& Tynan, C. 1999. 'In sickness and in health: Exploring and redeveloping a measure of marketing effectiveness', Journal of Marketing Management, 15(8): 733-756.

Cooper, D. R. \& Emory, C. W. 1995. Business research methods. 5th Edition. London: Irwin.

Covin, J. G. \& Slevin, D. P. 1989. 'The strategic management of small firms in hostile and benign environments', Strategic Management Journal, 10(1): 7587.

Cragg, P. B. \& King, M. 1993. 'Small firm computing: Motivators and inhibitors’, MIS Quarterly, 17(1): 47-60.

DeLone, W. 1988. 'Determinants of success for computer usage in small business’, MIS Quarterly, 12(1): 51-61.

Durkin, M. \& McGowan, P. 2001. “ “Net Effect” - Views from the periphery: Exploring the role and importance of the internet on marketing activity in entrepreneurial firms', Irish Marketing Review, 14(1): 15-25.

Fabrigar, L. R., Wegener, D. T., MacCullum, R. C. \& Strahan, E. J. 1999. 'Evaluating the use of exploratory factor analysis in psychological research', Psychological Methods, 4: 272-299.

Gilmore, A., Carson, D. \& Grant, K. 2001. 'SME marketing in practice’, Market Intelligence and Planning, 19(1): 6-11.

Gorsuch R. L. 1997. 'Exploratory factor analysis: Its role in item analysis', Journal of Personality Assessment, 68(3): 532-560. 
Graham, P. G. 1999. 'Small business participation in the global economy', European Journal of Marketing, 33(1/2): 88-102.

Gray, B., Matear, S., Boshoff, C. \& Matheson, P. 1998. 'Developing a better measure of market orientation', European Journal of Marketing, 32(9/10): 884-903.

Greenley, G. E. 1995. 'Market orientation and company performance: Empirical evidence from UK companies', British Journal of Management, 6(1): 1-13.

Guzman-Cuevas, J. 1994. 'Towards a taxonomy of entrepreneurial theories (Entrepreneurial theory from the 18th century)', International Small Business Journal, 12(4): 77-86.

Hair, J. F., Anderson, R. E., Tatham, R. L. \& Black, W. C. 1998. Multivariate data analysis. $5^{\text {th }}$ Edition. Englewood Cliffs, New Jersey: Prentice Hall.

Haynes, P. J., Becherer, R. C. \& Helms, M. M. 1998. 'Small and mid-sized businesses and Internet use: Unrealised potential?', Internet research: Electronic networking applications and policy, 8(3): 229-235.

Hills, G. E. \& LaForge, R. W. 1992. 'Research at the marketing interface to advance entrepreneurship theory', Entrepreneurship Theory and Practice, 16(3): 33-59.

Hisrich, R. D. 1992. 'The need for marketing in entrepreneurship', Journal of Business and Industrial Marketing, 7(3): 53-57.

Hoffman, D. L. \& Novak, T. P. 1996. 'Marketing in hypermedia computer-mediated environments: Conceptual foundations', Journal of Marketing, 60(3): 50-68.

Hoffman, D. L. \& Novak, T. P. 1997. 'A new marketing paradigm for electronic commerce', The Information Society, 13(1): 43-54.

Hoffman, D. L., Novak, T. P. \& Chatterjee, P. 1995. 'Commercial scenarios for the Web: Opportunities and challenges', Journal of Computer-Mediated Communication, 1(3). [online] URL:http: //shum huji.ac.il/jcmc/vol1/ issue3 /hoffman html. Accessed 7 November 2001.

Hurley, R. F. \& Hult, G. T. M. 1998. 'Innovation, market orientation, and organizational learning: An integration and empirical examination', Journal of Marketing, 62(3): 4254.

Jones, C., Hecker, R. \& Holland, P. 2003. 'Small firm Internet adoption: Opportunities forgone, a journey not begun', Journal of Small Business and Enterprise Development, 10(3): 287-297.

Khandwalla, P. N. 1977. The design of organizations. New York: Harcourt Brace Jovanovich.
Kohli, A. K. \& Jaworski, B. J. 1990. 'Market orientation: The construct, research propositions, and managerial implications', Journal of Marketing, 54(2): 1-18.

Lafferty, B. A. \&. Hult, G. T. M. 2001. 'A synthesis of contemporary market orientation perspectives', European Journal of Marketing, 35(1/2): 92-109.

McGowan, P. \& Durkin, M. 2002. 'Toward an understanding of Internet adoption at the marketing/entrepreneurship interface', Journal of Marketing Management, 18(3/4): 361-377.

McGowan, P., Durkin, M., Allen, L., Dougan, C. \& Nixon, S. 2001. 'Developing competencies in the entrepreneurial small firm for use of the Internet in the management of customer relationships', Journal of European Industrial Training, 25(2/3/4): 126-136.

Megginson, W. L., Byrd, M. J. \& Megginson, L. C. 2000. Small business management: An entrepreneurs guidebook. $3^{\text {rd }}$ Edition. Boston: Irwin McGraw-Hill.

Mehrtens, J., Cragg, P. B. \& Mills, A. M. 2001. 'A model of Internet adoption by SMEs', Information and Management, 39(3): 165-176.

Miller, D. 1983. 'The correlates of entrepreneurship in three types of firms’, Management Science, 29(7): 770-791.

Miller, D. \& Friesen, P. H. 1983. 'Strategy-making and environment: The third link', Strategic Management Journal, 4(3): 221-235.

Morgan, R. E., Katsikeas, C. S. \& Appuh-Adu, K.1998. 'Market orientation and organisational learning', Journal of Marketing Management, 14(4/5): 353-381.

Morris, M. H., Kuratko, D. F. \& Schindehutte, M. 2001. 'Towards integration: Understanding entrepreneurship through frameworks', International Journal of Entrepreneurship and Innovation, 2(1): 35-49.

Myles, P. 2003. Personal communication. Tourism consultant, Port Elizabeth 8 October.

Narver, J. C. \& Slater, S. F. 1990. 'The effect of a market orientation on business profitability', Journal of Marketing, 54(4): 20-35.

Ntsika (Ntsika Enterprise Promotion Agency). 1998. State of small business in South Africa. Pretoria: Ntsika Enterprise Promotion Agency.

Ntsika (Ntsika Enterprise Promotion Agency). 2002. State of small business in South Africa. Pretoria: Ntsika Enterprise Promotion Agency.

O’Toole, T. 2003. 'E-relationships- emergence and small firms', Marketing Intelligence and Planning, 21(2): 115122. 
Palmer, A. 2005. Principles of services marketing. $4^{\text {th }}$ Edition. Glasgow: McGraw-Hill.

Parasuraman, A. 1991. Marketing research. $2^{\text {nd }}$ Edition. Reading: Addison-Wesley.

Pelham, A. M. 2000. 'Market orientation and other potential influences on performance in small and medium-sized manufacturing firms', Journal of Small Business Management, 38(1): 48-67.

Pelham, A. M. \& Wilson, D. T. 1996. 'A longitudinal study of the impact of market structure, firm structure, strategy, and market', Journal of the Academy of Marketing Science, 24(1): 27-43.

Pitt, L. 1996. 'Report on the small and medium enterprise provincial study tour: November 1996'. [online] URL: http: //www.polity.org.za/govdocs/parliment/committees/trade/we bdoc.html. Accessed 15 October 2001.

Pitt, L., Caruana, A. \& Berthon, P. 1996. 'Market orientation and business performance: Some European evidence', International Marketing Review, 13(1): 5-18.

Poon, S. \& Swatman, P. M. C. 1997. 'Small business use of the Internet: Findings from Australian case studies', International Marketing Review, 14(5): 385-402.

Remenyi, D. 2000. 'E-biz - The great hunt for the golden fleece'. Paper presented at the Southern Africa Institute for Management Scientists (SAIMS) 2000 conference, 31 October - 2 November 2000, University of South Africa, Midrand, South Africa.

Rogers, E. M. 1995. Diffusion of innovations. 4th Edition. New York: Free Press.

Rogerson, C. M. 2003. 'Tourism and transformation: Small enterprise development in South Africa', Africa Insight, 33(1/2): 108-115.

Schumpeter, J. A. 1934. The theory of economic development - An enquiry into profits, capital, credit, interest, and the business cycle. Cambridge, Mass.: Harvard University Press.

Schumpeter, J. A. 1942. Capitalism, socialism and democracy. New York: Harper and Brothers Publishers.

Sekaran, U. 2000. Research methods for business: A skill building approach. $3^{\text {rd }}$ Edition. New York: John Wiley.

Seymour, J. 2002. Personal e-mail from James Seymour, Market Research and Information Systems Manager, Tourism KwaZulu-Natal: 25 April.

South Africa, Republic of, 1995. White paper on the national strategy for the development and promotion of small business in South Africa. [online] URL: http: //www.polity.org.za/govdocs/white_papers/smallbiz html.

Accessed 14 August 2001.
South Africa, Republic of 1996. White paper on the development and promotion of tourism in South Africa. Pretoria: Department of Environmental Affairs and Tourism.

South Africa, Republic of 1998. Tourism in gear: Tourism development strategy 1998-2000. Pretoria: Department of Environmental Affairs and Tourism.

Stansfield, M. \& Grant, K. 2003. 'An investigation into issues influencing the use of the Internet and electronic commerce among small-medium sized enterprises', Journal of Electronic Commerce Research, 4(1): 15-33.

Thong, J. \& Yap, C. S. 1995. 'CEO characteristics, organisational characteristics, and information technology adoption in small business', Omega, 23(4): 429-442.

Vargha, R. \& Pettigrew, S. F. 2001. 'Internet issues for small and medium sized Australian Business'. In Chetty, S. \& Collins, B. (Eds.). Proceedings of the Australian and New Zealand Marketing Academy (ANZMAC) conference 2001, 1st - 5th December 2001, Massey University (Albany Campus), Auckland, New Zealand.

Venkatesan, V. S. \& Soutar, G. 2000. 'The applicability of some market orientation models to Australian SMEs: An empirical study'. In O'Cass, A. (Ed.). Proceedings of the Australian and New Zealand Marketing Academy (ANZMAC) conference 2000, 28th November - 1st December 2000, Griffith University, Gold Coast, Queensland, Australia.

WTTC (World Travel and Tourism Council). 2002. South Africa: The impact of travel and tourism on jobs and the economy - 2002 plus special report on September $11^{\text {th }}$ impacts. London: World Travel and Tourism Council.

WTTC (World Travel and Tourism Council). 2003. South Africa: Travel and tourism a world of opportunity. London: World Travel and Tourism Council.

Wu, F., Mahajan, V. \& Balasubramanian, S. 2003. 'An analysis of e-business adoption and its impact on business performance', Journal of the Academy of Marketing Science, 31(4): 425 -447.

Yeung, J. H. Y., Shim, J. P. \& Lai, A. Y. K. 2003. 'Current progress of e-commerce adoption: Small and medium enterprises in Hong Kong', Communications of the ACM, 46(9): 226-232.

Zimmerer, T.W. \& Scarborough, N.M. 2002. Essentials of entrepreneurship and small business management. $3^{\text {rd }}$ Edition. New Jersey: Prentice Hall. 


\begin{tabular}{|c|c|}
\hline OI5 & $\begin{array}{l}\text { The owner-manager actively participates in managing the Internet for the marketing of our } \\
\text { business }\end{array}$ \\
\hline OI6 & The owner-manager makes time to manage the Internet marketing of our business \\
\hline EO6 & $\begin{array}{l}\text { In dealing with its competitors, our business is very often the first business to introduce new } \\
\text { products/services/packages and ways of marketing. }\end{array}$ \\
\hline EO1 & $\begin{array}{l}\text { Our firm constantly explores the development of new business ideas (for example new } \\
\text { packages and products) }\end{array}$ \\
\hline EO5 & In the last few years, our business has added very many new features to our service(s). \\
\hline EO2 & $\begin{array}{l}\text { In the last few years, changes in the nature of our service (for example features of our service } \\
\text { and/or the packages offered) have usually been quite significant. }\end{array}$ \\
\hline EO3 & Our business is innovative in the way it markets itself and/or its products \\
\hline EO8 & $\begin{array}{l}\text { In dealing with its competitors, our business typically initiates actions which competitors then } \\
\text { respond to }\end{array}$ \\
\hline EO4 & We constantly refine and develop existing services/ packages \\
\hline EO10 & $\begin{array}{l}\text { In order to maximize the probability of exploiting potential opportunities our business will } \\
\text { typically make bold and aggressive decisions }\end{array}$ \\
\hline EO9 & $\begin{array}{l}\text { Our business believes that owing to the nature of the environment, bold and wide-ranging } \\
\text { actions are necessary to achieve the business's objectives }\end{array}$ \\
\hline COM2 & We respond rapidly to competitors' actions \\
\hline SUC2 & $\begin{array}{l}\text { I am satisfied that the use of the Internet for marketing results in increased bookings for our } \\
\text { business }\end{array}$ \\
\hline SUC8 & $\begin{array}{l}\text { I am satisfied that use of the Internet improves the effectiveness of advertising and promoting } \\
\text { our business }\end{array}$ \\
\hline SUC9 & I am satisfied that the Internet enhances our customer service \\
\hline SUC10 & $\begin{array}{l}\text { I am satisfied that the Internet assists us in conveying information about our business to } \\
\text { customers }\end{array}$ \\
\hline SUC3 & I am satisfied that our Web Site assists us in getting referrals (word of mouth) \\
\hline SUC5 & I am satisfied that use of the Internet for marketing assists us in getting repeat business \\
\hline SUC7 & I am satisfied that use of the Internet improves the image of our business \\
\hline SUC4 & I am satisfied that the Internet assists us in maintaining relationships with existing customers \\
\hline SUC6 & $\begin{array}{l}\text { I am satisfied that the Internet improves our ability to find out information about customers, } \\
\text { competitors and the tourism industry }\end{array}$ \\
\hline SUC1 & I am satisfied that Internet marketing reduces our marketing costs \\
\hline TK3 & The owner-manager is knowledgeable about the use of the Internet for marketing \\
\hline TK4 & The owner-manager understands enough about Internet marketing to make informed decisions \\
\hline TK5 & The owner-manager knows what is required to make the Internet effective for marketing \\
\hline TK2 & The owner-manager understands the issues surrounding the use of the Internet for marketing \\
\hline OI4 & The owner-manager closely monitors the progress of the Internet marketing of our business \\
\hline OI2 & $\begin{array}{l}\text { The owner-manager is involved in decision-making about the Internet marketing of our } \\
\text { business }\end{array}$ \\
\hline OI3 & Most decisions about the Internet marketing of our business are made by the owner-manager \\
\hline CUS4 & We monitor customer satisfaction on a regular basis \\
\hline COM6 & We understand the nature of our competition \\
\hline COM3 & We know our competitors well \\
\hline CUS6 & We encourage customer comments and complaints because they help us do a better job \\
\hline COM4 & We are aware of how our competitors market their products \\
\hline CUS7 & We are quick to detect changes in customers' preferences \\
\hline
\end{tabular}


